\title{
REJECTION CHARACTERISTICS OF ORGANOCHLORINE PESTICIDES BY LOW PRESSURE REVERSE OSMOSIS MEMBRANE
}

\author{
Woro Nastiti Utami ${ }^{11}$, Rofiq Iqba| ${ }^{2)}$, and I Gede Wenten ${ }^{3)}$ \\ 1,2) Study Program of Environmental Engineering, Faculty of Civil and Environmental \\ Engineering, Institut Teknologi Bandung, Jl Ganesa 10 Bandung, \\ rock neve dies@yahoo.co.id and rofiq.iqbal@gmail.com \\ 3) Study Program of Chemical Engineering, Faculty of Industrial Engineering, Institut \\ Teknologi Bandung, JI Ganesa 10 Bandung, igwenten@yahoo.com
}

\begin{abstract}
The increased use of pesticides has led to many benefits such as advanced productivity and lower maintenance costs in agriculture. On the other hand, their adverse effects have also grown : an increase of the risks to the ecosystem and human health. Pressure driven technique such as reverse osmosis and nanofiltration have the potentiality to remove hazardous organic micropollutants such as pesticides. The rejection characteristic of artificial water with 10 ppb concentration of endosulfan and organochlorine pesticides from upper Citarum water shed sample were investigated with a commercial low pressure reverse osmosis unit on laboratory scale. Rejection and flux were measured with a varied operational parameters ; $\mathrm{pH}$, pressure, and feed concentration. Endosulfan rejection was achieved $>80 \%$ with all varied operational parameters. There was a little dependence permeate flux and percent of rejection on $\mathrm{pH}$. An increasing pressure caused a higher permeate flux while there was no effect of an increasing pressure to higher percentage of endosulfan rejection. An increasing feed concentration caused a lower permeate flux due to an increasing osmotic pressure. An increasing feed concentration also result in an increasing percent of endosulfan rejection. Organochlorine pesticides found in river water sample which are lindane, aldrin, and heptachlor were all rejected $100 \%$. This may be caused by natural organic matter present in river water and hydrophobicity. Percent rejection was constant to pressure and $\mathrm{pH}$ variation.
\end{abstract}

Keywords : Low Pressure Reverse Osmosis, Organochlorine Pesticides, Pressure, $\mathrm{pH}$, Feed Concentration

\subsubsection{INTRODUCTION}

Pesticides, even at comparatively low concentrations, make water unfit for direct municipal supply. Organochlorine pesticides (OCPs), banned for its toxicity and persistency are still mainly used in agricultural sector in Indonesia. OCPs are very resistant to microbial degradation. They can, therefore, accumulate in human body fats and the environment posing problem to human health. Organochlorine pesticides can be classified into three main classes which are hexachlorocyclohexane (lindane), cyclodienes (aldrin, dieldrin, endrin heptachlor, endosulfan), and derivate chlorinated ethan (DDT). Endosulfan, an organochlorine pesticides mainly used in agricultural sector in Kecamatan Kertasari Kabupaten Bandung $(22.31 \%)^{(8)}$ is listed as highly acutely toxic by US-EPA.

It was also considered as the most organochlorine pesticides found in Upper Citarum water shed ${ }^{(1)}$. Endosulfan $\left(\mathrm{C}_{9} \mathrm{H}_{6} \mathrm{Cl}_{6} \mathrm{O}_{3} \mathrm{~S}\right)$ has molecular weight of $406.95 \mathrm{~g} / \mathrm{mol}$ and log Kow equal to 3,83 (alpha endosulfan) and 3,62 (beta endosulfan). There are various methods (e.g., granular activated carbon, ozonation) to separate pesticides from water. As they are expensive and bear limitation, membrane separation technique is the preferable one because of the inherent characteristics, low cost energy consumption, and simple operation (2). RO can be described as diffusion-controlled process in which mass transfer of ions through RO membranes is controlled by diffusion. Physical holes may not exist in an RO membrane, which distinguishes RO membrane with other filtration system. RO membrane is very hydrophilic; therefore water will be able to readily diffuse into and out of the polymer structure of the membrane (9). Several studies have been conducted for pesticides removal by nanofiltration and reverse osmosis.

A study revealed that the highest rejection of aldrin was achieved Desal $51 \mathrm{HL}$ $(97.1 \%)$ and the highest rejection of dieldrin was achieved by N30F (99\%) with single stage filtration (4). While there was only a few studies focused on organochlorine pesticide separation by membrane filtration. The aim of this study is to 
know rejection characteristic of low pressure reverse osmosis for removal organochlorine pesticides with a varied $\mathrm{pH}$, pressure, and feed concentration

\subsubsection{MATERIALS AND METHODS}

\subsection{Endosulfan Separation}

\subsubsection{Experimental Solution}

Artificial solution was made from distilled water to obtain a sample with endosulfan at concentration equal to $10 \mu \mathrm{g} / \mathrm{L}$ (ppb). The $\mathrm{pH}$ of tested solution amounted to 5,7,9. The $\mathrm{pH}$ correction was made by adding $\mathrm{H}_{2} \mathrm{SO}_{4}(2 \mathrm{~N})$ or $\mathrm{NaOH}(1 \mathrm{M})$ solutions.

\subsubsection{Membrane Specification}

In this study, membrane used is low pressure reverse osmosis. The material is polyamide thin film composite membrane whose active area is $0.25 \mathrm{~m}^{2}$. This is a hydrophilic membrane ; negatively charged membrane. Its operational $\mathrm{pH}$ range is $2-11$, and maximum applied pressure is 21 bar. Water recovery membrane was measured during separation process. Water recovery increased in line with an increasing operational pressure and it ranges from $\pm 3-15 \%$ (applied pressure : 0.8-5 bar). The equation of water recovery is described in equation 1 below :

water recovery $=\frac{q_{p}}{q_{f}} \times 100 \%$

Where :

$\mathrm{q}_{\mathrm{p}}$ : permeate flow $(\mathrm{L} / \mathrm{s})$

$\mathrm{q}_{\mathrm{f}}$ : feed flow $(\mathrm{L} / \mathrm{s})$

\subsubsection{Analytical Methods}

Endosulfan concentration in permeate was extracted by dichloromethane n-hexane solvent and measured by gas chromatography.

\subsubsection{Assessments of Separation}

To estimate the separation of the membranes under study, the use of the following two parameters were studied:

1. Flux measurement

2. Percent rejection of endosulfan

Variations used are $\mathrm{pH}$ (5-9), operational pressures (2-5 bar), and feed concentration $(5,15,25 \mathrm{ppb})$. Samples were taken from 2 hours of operation. Separation process by low pressure reverse osmosis is presented in Figure 1.

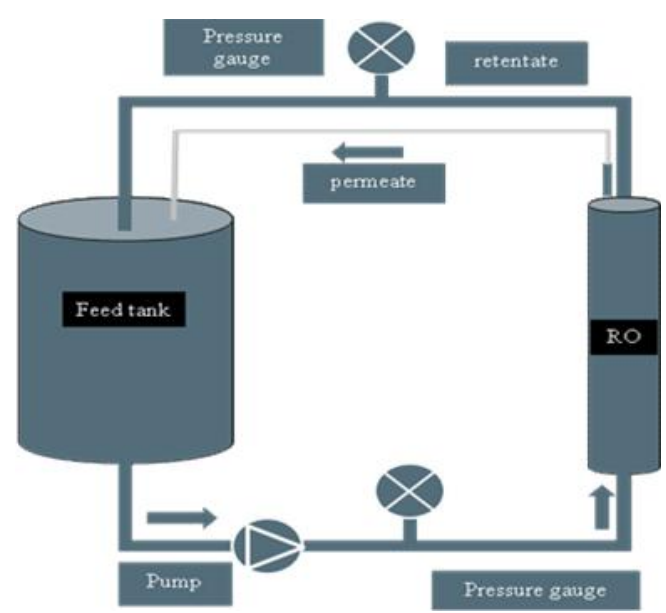

Figure 1. Separation Process by Low Pressure Reverse Osmosis Membrane

\subsection{River Water Contaminated of Organochlorine Pesticide Separation}

\subsubsection{Sampling}

Water sample was collected from one point of Upper Citarum water shed on August 2009. 30 liter of sample was collected. Method used was composite sampling and sample was taken in $0.5 \mathrm{~m}$ depth from water surface.

\subsubsection{Analytical Methods}

Sample of river water was pre analyzed by extraction (dichloromethane n-hexane) and measurement (gas chromatograph).

\subsubsection{Pretreatment by Ultrafiltration}

Pretreatment was conducted using ultrafiltration with recycle process to remove suspended materials. The material of membrane was PAN with active area of $0.5 \mathrm{~m}^{2}$. The output of ultrafiltration process becomes an input of reverse osmosis process. This process was conducted to remove suspended materials.

\subsubsection{Assessment of Separation}

To estimate the separation of the membranes under study, the use of the following two parameters were studied:

1. Flux measurement

2. Percent rejection of endosulfan

Variations used are $\mathrm{pH}$ (5-9), operational pressures (2-5 bar). Samples were taken from permeate after 2 hours of operation. 


\section{RESULT AND DISCUSSION}

\subsection{Effect of $\mathrm{pH}$ to Endosulfan Separation}

Before endosulfan separation process with $\mathrm{pH}$ variation, membrane permeability test is conducted. Membrane permeability is 10.33 $\mathrm{L} / \mathrm{m} 2$.h.bar. Effect $\mathrm{pH}$ variation to endosulfan rejection and permeate flux is presented in Figure 2.

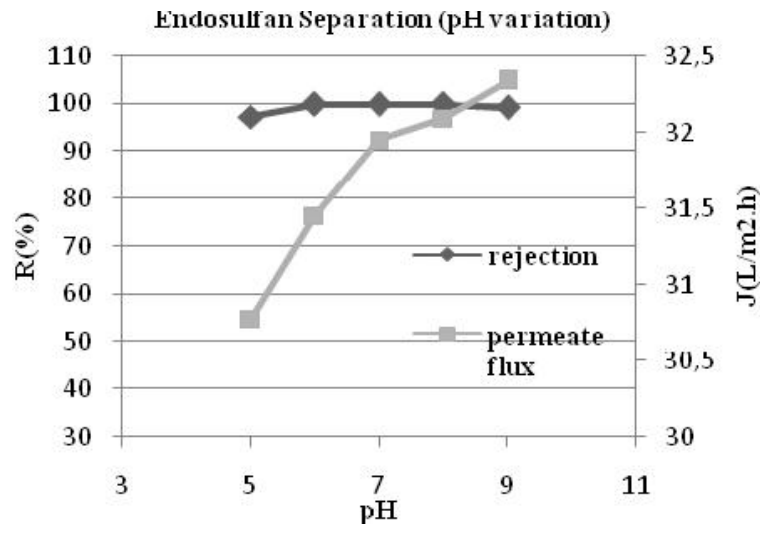

Figure 2. Effect pH to Endosulfan Separation

Several researchers have found little dependence of permeate flux on $\mathrm{pH}$ unless ions are present in the feed solution. In endosulfan separation, there is a little dependence flux on $\mathrm{pH}$ since endosulfan is an uncharged compound. Besides, endosulfan cannot dissociate (at $\mathrm{pH}$ ranged from 5-9) based on its molecular structure, therefore $\mathrm{pH}$ did not effect on separation process by electrostatic repulsion mechanism. Separation mechanism of undissociated organic compound was considered as size exclusion mechanism.

\subsection{Effect of Pressure to Endosulfan Separation}

Membrane permeability for pressure variation is $10.16 \mathrm{~L} / \mathrm{m} 2$.h.bar. Effect Pressure to Endosulfan rejection is presented in Figure 3. Based on pressure variation to membrane flux, membrane flux increased with an increased pressure. Water permeability across membrane is influenced by two factors which are solubility and diffusion. Diffusion is influenced by interaction between membrane pores and water molecules. A higher pressure given to membrane made water molecules become easier to diffuse through membrane pores. A higher pressure caused a higher flux. On endosulfan rejection, an increasing pressure did not have an effect on endosulfan rejection. These can be seen from the constant percent rejection of endosulfan with varied pressure. It was caused by less sensitive pore in TFC polyamide low pressure reverse osmosis membrane to pressure variation ${ }^{(5)}$. The active pores did not increase with an increasing pressure, therefore pressure variation has no effect on increasing endosulfan rejection.

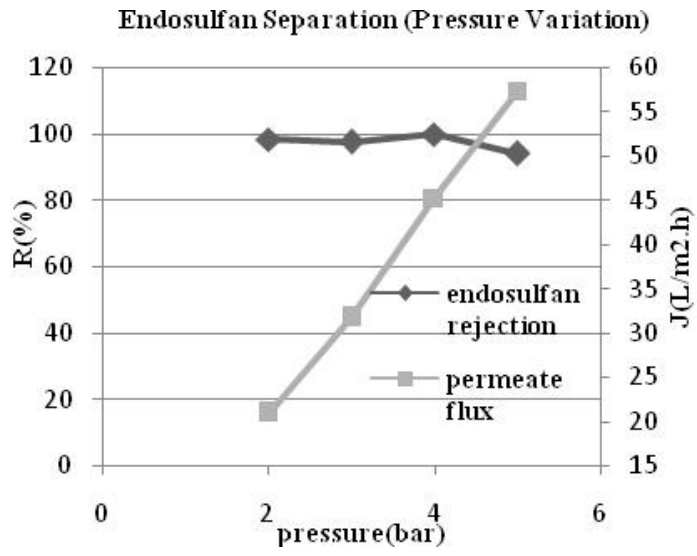

Figure 3

Effect Pressure to Endosulfan Separation

\subsection{Effect of Feed Concentration to Endosulfan Rejection}

Membrane permeability measured before separation process was $10.84 \mathrm{~L} / \mathrm{m}^{2}$.h.bar. An increasing feed concentration caused a decreasing permeate flux. It was caused by an increasing osmotic pressure which was influenced by molar concentration of solute. An increasing osmotic pressure lead to decreasing permeate flux. This was also according to Hagen Poiseuille law which stated that an increasing osmotic pressure results in a decreasing solvent flux. In neutral trace organic rejection by reverse osmosis, there was a decreasing diffusivity contribution caused by an increasing solute concentration (6).

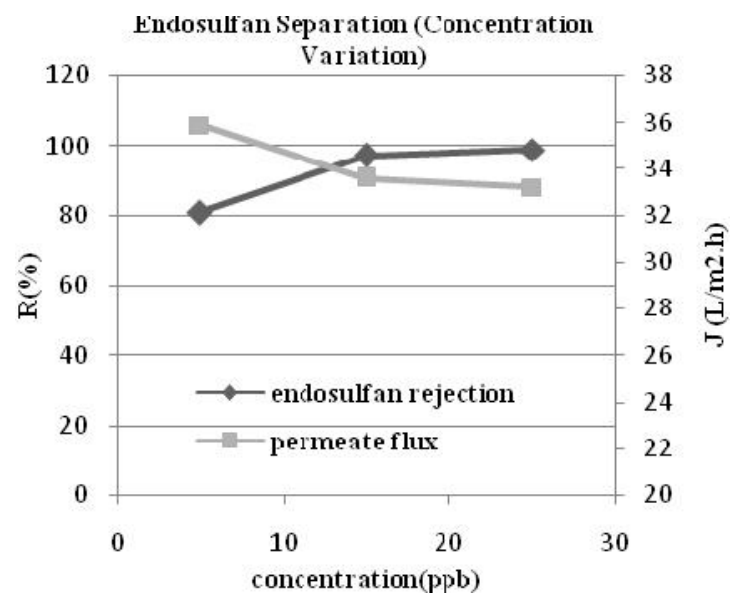

Figure 4. Effect Concentration to Endosulfan Separation 
It also revealed that an increasing diffusivity contribution lead to an increasing convection contribution in solute transport mechanism. A decreasing diffusivity contribution resulted in decreasing solute flux, therefore solute amount which permeates through membrane decreased. This leads to an increasing percent of endosulfan rejection.

\subsection{Separation Process of Organochlorine Pesticides by LPRO}

Pretreatment by ultrafiltration was conducted in order to separate macro solutes from water and micro solutes. In pretreatment by ultrafiltration, permeate flux declined during operational time. The declined permeate flux was influenced by contaminant macromolecules which accumulated in membrane's surface. This formed a new layer resulted in the declined flux during operational time. After being treated by ultrafiltration, river water sample was pre analyzed by extraction and measurement. Flux measurement during operational time is presented in Figure 5. Meanwhile, the organoclorine compounds found in sample after ultrafiltration process are listed in Table1.

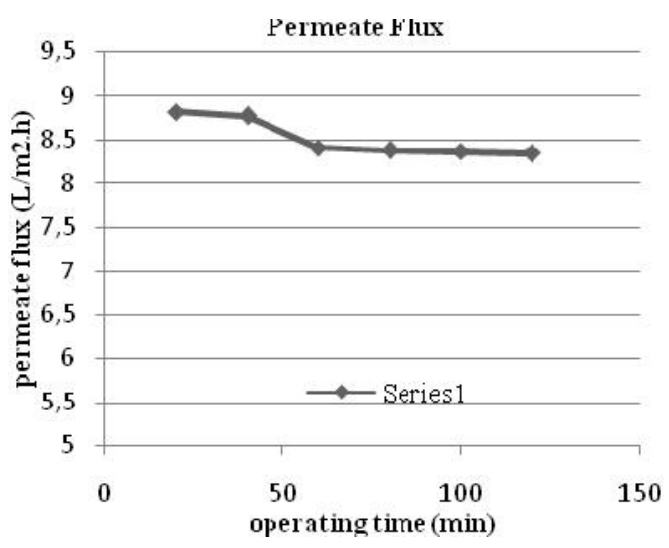

Figure 5. Permeate Flux (River water) by Ultrafiltration

Table 1. Organochlorine Pesticides Found in Ultrafiltration Output

\begin{tabular}{|l|l|}
\hline \multicolumn{1}{|c|}{ OCPs } & Sample (river water) \\
\hline Lindane & $0.52 \mathrm{ppb}$ \\
\hline Heptachlor & $0.3 \mathrm{ppb}$ \\
\hline Aldrin & $0.05 \mathrm{ppb}$ \\
\hline
\end{tabular}

The output of ultrafiltration was then treated by low pressure reverse osmosis membrane with variation of $\mathrm{pH}$ and pressure. Membrane permeability measured before separation process (pressure variation) was $8.082 \mathrm{~L} / \mathrm{m}^{2}$ h. h.bar and membrane permeability measured before separation process $(\mathrm{pH}$ variation) was $7.236 \mathrm{~L} / \mathrm{m}^{2}$.h.bar. Effect of pressure variation to organochlorine pesticides removal is presented in Figure 6. Meanwhile effect of $\mathrm{pH}$ to organochlorine pesticides removal is presented in Figure 7.

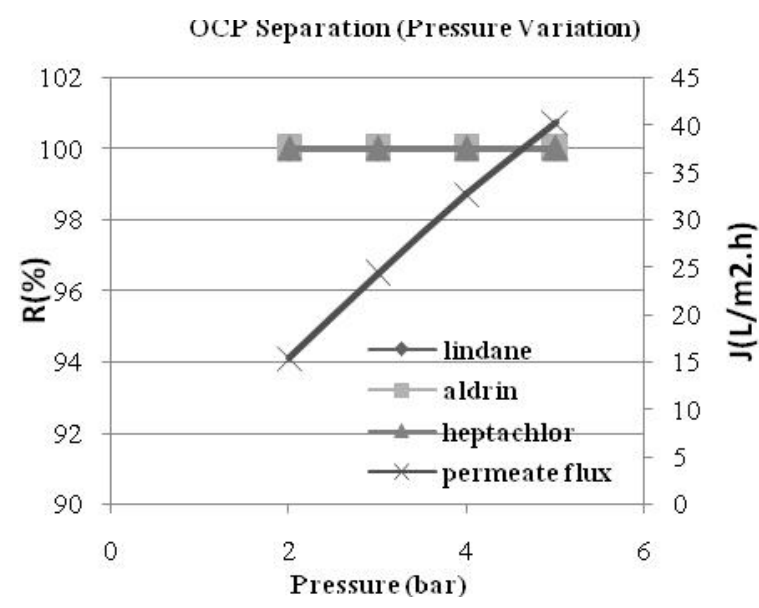

Figure 6. Effect Pressure to OCP Separation

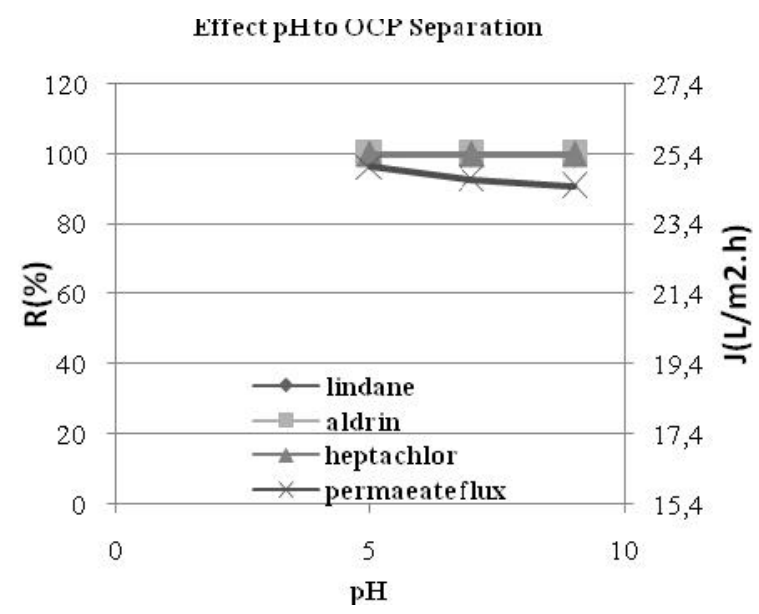

Figure 7. Effect $\mathrm{pH}$ to OCP Separation

Percent rejections of all measured organochlorine, i.e. lindane, aldrin, and heptachlor were all achieved $100 \%$. This may be due to water matrix influence. A complete rejection of organochlorine pesticides (aldrin, lindane, dieldrin) were also influenced by natural organic matter present in river water sample. Interaction between pesticides and natural organic matter formed complex macromolecules that lead to decreasing diffusion rate through membrane material. This caused an increasing percent of rejection. Natural organic matter existence can be described by total organic carbon measured from samples. TOC of samples is presented in Table 2. 
Table 2. Feed Water Quality

\begin{tabular}{|c|c|c|c|}
\hline Parameter & $\begin{array}{c}\text { River } \\
\text { water }\end{array}$ & $\begin{array}{c}\text { Ultrafiltration } \\
\text { Output (Feed 2) }\end{array}$ & $\begin{array}{c}\text { Aquadest } \\
\text { (Feed 1) }\end{array}$ \\
\hline $\begin{array}{c}\text { Tempe- } \\
\text { rature }\end{array}$ & $\begin{array}{c}26.7 \\
{ }^{\circ} \mathrm{C}\end{array}$ & $\begin{array}{c}27.3 \\
{ }^{\circ} \mathrm{C}\end{array}$ & $\begin{array}{c}25 \\
\pm 2{ }^{\circ} \mathrm{C}\end{array}$ \\
\hline $\mathrm{pH}$ & 7.48 & 7.32 & 7 \\
\hline $\mathrm{TOC}$ & 10.35 & 5.175 & 0 \\
\hline
\end{tabular}

Besides, lindane, aldrin, and heptachlor all have a high solute affinity for the membrane expressed through octanol water coefficient (Kow). In 2001, it was also reported that an increasing log Kow of organic solute lead to an increasing rejection of organic solute ${ }^{(7)}$.

\section{CONCLUSION}

Endosulfan rejection by LPRO achieved $\geq 80 \%$ ranged from $80-100 \%$. An increasing $\mathrm{pH}$ did not cause an increasing endosulfan rejection since endosulfan were an undissociated compound while there was a little dependence of flux on $\mathrm{pH}$ since endosulfan was uncharged molecule. A higher pressure caused a higher membrane flux but a higher pressure did not result in an increasing rejection since TFC (Thin Film Composite) membrane's pore was less sensitive to pressure variation.

An increasing feed concentration resulted in a decreasing permeate flux because of an increasing osmotic pressure. While an increasing feed concentration leaded to an increasing percent of rejection and this was caused by a decreasing diffusivity contribution. The percent rejection of lindane, aldrin, and heptachlor were all achieved $100 \%$. This rejection was influenced by natural organic matter present in river water sample and a high hydrophobicity of compounds.

\section{REFERENCES}

1. Adhiraga, Mochamad, "Profil penyebaran konsentrasi pestisida organoklorin pada air sungai subdas citarum hulu". Undergraduate Thesis, Faculty of Civil and Environmental Engineering - ITB, Bandung, 2009.

2. Bhattacharya A., P. Ray, H. Brahmbhatt, K. N. Vyas, S. V. Joshi, C. V. Devmurari, J. J. Trivedi., "Pesticides Removal by Low Pressure Reverse Osmosis Membrane". Wiley Periodicals, Inc. J Appl Polym Sci 102, pp 3575-3579, 2006.

3. Bellona, Christopher et all., "Factors affecting the rejection of organic solutes during NF/RO treatment - a literature review", Water research : 38, pp 2795-2809, 2004.
4. Causs, Alexander, at all .,"Integrated nanofiltration cascades with low salt rejection for complete removal of pesticides in drinking water production". Desalination 241, pp 111117, 2009.

5. Kos'utic', Kunst B.,"Porosity of some commercial reverse osmosis and nanofiltration polyamide thin-film composite membranes". J. Membr. Sci ;168, pp 101108, 1999.

6. Kim, Tae Uk., "Solute transport model for trace organic neutral and charged compounds through nanofiltration and reverse osmosis membranes". Water research : 41, pp 3977-3988, 2007.

7. Kiso Y, Kon T.,"Rejection properties of alkyl phthalates with nanofiltration membranes". J Membr Sci : 182, pp 205-14, 2001.

8. Rochmanti, Masayu Dian., "Identifikasi penggunaan pestisida pada ladang dan sawah", Undergraduate Thesis, Faculty of Civil and Environmental Engineering - ITB, Bandung, 2009.

9. Wenten, I Gede.,"Membrane in water and wastewater treatment". Dept.of Chemical Engineering - ITB, Bandung, 2008. 


\begin{abstract}
Abstrak
Peningkatan penggunaan pestisida membawa dampak positif seperti peningkatan produktifitas dan minimasi biaya perawatan di sektor pertanian. Tetapi, di lain pihak, penggunaan pestisida juga membawa dampak negatif:ancaman terhadap ekosistem dan aspek kesehatan. Aplikasi membrane seperti reverse osmosis dan nanofiltration cukup potensial untuk menghilangkan mikropolutan organik berbahaya seperti pestiside. Karakterisik rejeksi dari air buatan dengan konsentrasi endosulfan 10 ppb dan sampel Sungai Citarum dengan aplikasi reverse osmosis tekanan rendah menjadi fokus dalam penelitian ini. Rejeksi dan fluk LPRO dianalisis dengan variasi parameter operasional : $\mathrm{pH}$, tekanan, dan konsentrasi polutan di umpan. Tingkat rejeksi endosulfan dengan variasi parameter operasional adalah $>80 \%$. Variasi $\mathrm{pH}$ tidak berpengaruh pada fluk dan tingkat rejeksi sedangkan peningkatan tekanan meningkatkan fluk permeate membrane, namun tidak berpengaruh pada persen rejeksi endosulfan. Peningkatan konsentrasi polutan dalam umpan meningkatkan persen rejeksi polutan. Pestisida organoklorin yang ditemukan dalam sampel Sungai Citarum adalah : lindane, aldrin, dan heptachlor dan tingkat rejeksi LPRO terhadap ketiga polutan tersebut adalah $100 \%$. Hal ini mungkin dipengaruhi oleh Natural Organic Matter (NOM) di sungai dan hydrophobicity tinggi dari lindane, alrin, dan heptachlor. Persen rejeksi dari ketiga pestisida tersebut konstan terhadap variasi tekanan dan $\mathrm{pH}$.
\end{abstract}

Kata kunci : reverse osmosis tekanan rendah, pestisida organoklorin, tekanan, $\mathrm{pH}$, dan umpan

\begin{abstract}
The increased use of pesticides has led to many benefits such as advanced productivity and lower maintenance costs in agriculture. On the other hand, their adverse effects have also grown : an increase of the risks to the ecosystem and human health. Pressure driven technique such as reverse osmosis and nanofiltration have the potentiality to remove hazardous organic micropollutants such as pesticides. The rejection characteristic of artifical water with $10 \mathrm{ppb}$ concentration of endosulfan and organochlorine pesticides from upper Citarum water shed sample were investigated with a commercial low pressure reverse osmosis unit on laboratory scale. Rejection and flux were measured with a varied operational parameters ; $\mathrm{pH}$, pressure, and feed concentration. Endosulfan rejection was achieved $>80 \%$ with all varied operational parameters. There was a little dependence permeate flux and percent of rejection on $\mathrm{pH}$. An increasing pressure caused a higher permeate flux while there was no effect of an increasing pressure to higher percentage of endosulfan rejection. An increasing feed concentration caused a lower permeate flux due to an increasing osmotic pressure. An increasing feed concentration also result in an increasing percent of endosulfan rejection. Organochlorine pesticides found in river water sample which are lindane, aldrin, and heptachlor were all rejected $100 \%$. This may be caused by natural organic matter present in river water and hydrophobicity. Percent rejection was constant to pressure and $\mathrm{pH}$ variation.
\end{abstract}

Keywords : Low Pressure Reverse Osmosis, Organochlorine Pesticides, Pressure, Ph, And Feed 